\title{
Layanan Bimbingan Kelompok dalam Membentuk Sikap Jujur Melalui Pembiasaan
}

\author{
Syifa Nur Fadilah \\ Universitas Islam Negeri (UIN) Sunan Kalijaga Yogyakarta \\ syifanurfadilah241@gmail.com
}

\begin{abstract}
The content of this article is about group guidance services to foster an honest attitude through conditioning. Honest attitude is a positive attitude that is owned by individuals, honesty can be formed through the environment in which the individual interacts. Group Guidance Service is one of the efforts of the counseling service program, which in the process of group guidance services utilizes group dynamics as a form of guidance effort by providing information about honesty material as an effort to habituate group guidance participants so that group guidance participants take advantage of their honest attitude to habituation in the environment where the individual is located. The method used refers to the type of qualitative-descriptive research using a library research approach, with the ultimate goal of obtaining a general and comprehensive picture of the efforts of group guidance services in forming honest attitudes.
\end{abstract}

Keywords: Guidance services group, honest attitude, conditioning

\begin{abstract}
Abstrak
Isi dari artikel ini adalah mencakup tentang layanan bimbingan kelompok untuk menumbuhkan sikap jujur melalui pembiasaan (conditioning). Sikap jujur merupakan sikap positif yang dimiliki individu, sikap jujur dapat dibentuk melalui lingkungan dimana individu tersebut berinteraksi. Layanan Bimbingan Kelompok adalah salah satu upaya dari program layanan bimbingan konseling, yang dalam prosesnya layanan bimbingan kelompok memanfaatkan dinamika kelompok sebagai bentuk usaha bimbingan dengan memberikan informasi-informasi tentang materi sikap jujur sebagai upaya pembiasaan peserta bimbingan kelompok agar peserta bimbingan kelompok memanfaatkan sikap jujurnya untuk pembiasaan dilingkungan dimana individu tersebut berada. Metode
\end{abstract}


yang dilakukan merujuk pada jenis penelitian deskriptif-kualitatif menggunakan pendekatan kajian pustaka (Library Research), dengan tujuan akhir memperoleh gambaran secara umum dan menyeluruh tentang upaya layanan bimbingan kelompok dalam membentuk sikap jujur.

Kata Kunci: Layanan bimbingan kelompok, sikap jujur, pembiasaan

\section{Pendahuluan}

Sikap/karakter yang dimiliki individu berasal dari perilaku yang biasa individu lakukan didalam kehidupan dimana individu itu berada, dalam artian seseorang akan melakukan sesuatu diperoleh dari kebiasaan/pembiasaan yang ada di dalamlingkungannya, begitu pula dengansikapjujur.

Bagian dari sikap positif yang dimiliki individu salah satunya adalah kejujuran, individu yang menekankan kejujuran didalam kehidupan dan kesehariannya akan merasa dirinya tentram tanpa ada tekanan batin. Ketika ucapan yang diungkapkan tidaklah sesuai dengan kenyataan, individu akan merasa risau, selalu dihantui dengan ketidak jujuran yang diungkapkannya kepada orang lain, tidak sedikit individu yang merasa dirinya takut ketika bertemu dengan orang lain karena ucapan dan perilaku dirinya telah berlaku tidak jujur.

Kejujuran merupakan harga mahal yang harus dimiliki seseorang, tanpa adanya sikap jujur akan menimbulkan sikap tidak percaya orang lain kepada individu yang dirasa tidak jujur, dan hal tersebut akan menghambat interaksi antara individu dengan hubungan sosialnya.Sikap jujur menurut Samani dan Hariyanto 1 ialah suatu sikap yang menyatakan apa yang ada sebenarnya, terbuka, serta konsisten terhadap apa yang dikatakan dan yang dilakukan (berintegritas), memiliki keberanian karena benar, mampu di percaya (amanah, trustworthisness), dan tidak melakukan kecurangan (no cheathing).

Artinya sikap jujur mempunyai arti yang menyatakan bahwa individu yang jujur mampu dengan terbuka menyatakan apa yang sebenarnya, serta menyelaraskan antara apa yang dikatakan dan apa yang hendak dilakukan sehingga mampu membuat lingkungan serta orang lain percaya terhadap dirinya sendiri.

Dalam proses layanan bimbingan kelompok, mengharuskan setiap anggota yang ada dikelompok bimbingan menceritakan apa yang menjadi masalah pribadinya, hal ini bertujuan untuk anggota kelompok bersikap jujur

\footnotetext{
${ }^{1}$ M. Samani dan Hariyanto. Konsep dan Model Pendidikan Karakter, Bandung: PT Remaja Rosdakarya, 2012, hlm 51.
} 
dan terbuka, hal ini seperti yang di kemukakan oleh Prayitno ${ }^{2}$ bahwa tujuan dari bimbingan kelompok adalah untuk melatih individu berani mengemukakan pendapat dihadapan individu lainnya, melatih individu untuk dapat bersikap terbuka di dalam kelompok, membina keakraban bersama individu lainnya, melatih individu untuk dapat mempunyai tenggang rasa dengan orang lain, melatih individu memperoleh keterampilan sosial serta membantu individu dalam mengenali dan memahami dirinya dalam hubungannya dengan orang lain.

Dari tujuan layanan bimbingan kelompok tersebut bahwasanya bimbingan kelompok bertujuan untuk melatih individu mampu mengemukakan pendapatnya dengan terbuka artinya melatih individu untuk berlaku jujur baik pada dirinya sendiri maupun orang lain khususnya didalam tahapan kegiatan bimbingan kelompok berlangsung.

Berdasarkan pemaparan tersebut, penulis terdorong untuk mengkaji dengan metode penelitian dalam tulisan ini merujuk pada jenis penelitian deskriptif-kualitatif menggunakan pendekatan kajian pustaka (Library Research), dengan tujuan akhir memperoleh gambaran secara umum dan menyeluruh tentang upaya layanan bimbingan kelompok dalam membentuk sikap jujur

\section{Hasil dan Pembahasan}

\section{Layanan Bimbingan Kelompok}

Bimbingan kelompok adalah proses pengarahan yang dilakukan oleh seorang pembimbing (fasilitator) di dalam lingkup kelompok dalam satu waktu.

Menurut Titiek Romlah dalam bukunya bahwasanya bimbingan kelompok adalah proses pemberian bantuan yang diberikan individu dalam situasi kelompok dengan tujuan mencegah timbulnya suatu masalah yang menghambat pengembangan potensi individu. ${ }^{3}$ Sedangkan Menurut Prayitno, (dalam Bambang) menyatakan bahwa bimbingan kelompok yakni memanfatkan suatu dinamika yang berbentuk kelompok untuk upaya mencapai tujuan dari bimbingan dan konseling. ${ }^{4}$

Berdasarkan dari pendapat tersebut bahwa bimbingan kelompok pada dasarnya adalah usaha kegiatan yang memanfaatkan dinamika kelompok atau kumpulan sekelompok individu yang membentuk suatu kelompok sebagai upaya bimbingan yang dilakukan dan dilaksanakan seseorang (fasilitator) dengan tujuan mengembangkan suatu aspek yang terdapat dalam diri individu berupa sikap,

2 Prayitno, Dasar-dasar Bimbingan dan Konseling, Proses Belajar Mengajar, Jakarta :Rineka Cipta, 2000, hlm. 238.

3 Titiek Romlah, Teori dan Praktek Bimbingan Kelompok, Malang: Universitas Negeri Malang, 2001, hlm 3.

${ }^{4}$ Bambang Syamsul Arifi, Dinamika Kelompok, Bandung: CV Pustaka Setia, 2015, hlm 148. 
keterampilan, dan keberanian yang dimensinya bersangkut paut dengan orang lain yang bersifat sosial.

\section{Tujuan Layanan Bimbingan Kelompok}

Dalam melaksanakan suatu kegiatan tujuan pencapaian akan selalu ada, begitu pula dengan layanan bimbingan kelompok. Beberapa pandangan tentang tujuan bimbingan kelompok, Crow and Crow (dalam Chasiyah dkk) 5 mengemukakan tujuan dari layanan bimbingan kelompok, berupa (1) Bimbingan kelompok ditunjukan untuk memberikan dan memperoleh informasi dari individu, (2) Mengadakan usaha analisa dan pemahaman bersama tentang sikap, minat dan pandangan yang berbeda dari tiap-tiap individu, (3) Membantu memecahkan masalah dengan bersama-sama dan (4) untuk menemukan masalah pribadi yang ada pada tiap individu.

Selain itu Prayitno ${ }^{6}$ mengemukakan bahwa tujuan bimbingan kelompok dibagi menjadi dua bagian, tujuan bimbingan kelompok umum dan tujuan bimbingan kelompok khusus. Tujuan bimbingan kelompok secara umum ialah bertujuan membantu individu yang mengalami masalah melalui prosedur kelompok, selain itu bimbingan kelompok dengan tujuan umum juga bertujuan mengembangkan pribadi masing-masing anggota kelompok melalui berbagai suasana yang menyenangkan maupun menyedihkan. Sedangkan secara khusus bimbingan kelompok bertujuan untuk melatih individu untuk dapat berani mengemukakan pendapat dihadapan individu lainnya, melatih individu untuk dapat bersikap terbuka di dalam kelompok, membina keakraban bersama individu lainnya, melatih individu agar memiliki tenggang rasa dengan orang lain, melatih individu memperoleh keterampilan sosial, serta membantu individu dalam mengenali dan memahami dirinya dalam hubungannya dengan orang lain.

Tujuan layanan bimbingan kelompok seperti yag dikemukakan diatas, bahwa tujuan bimbingan kelompok sebenarnya untuk memberikan pengarahan terhadap peserta bimbingan kelompok dalam mengoptimalkan hubungan, baik dengan dirinya sendiri maupun hubungan dengan orang lain.

\section{Asas-asas Bimbingan Kelompok}

Adapun asas-asas yang ada didalam layanan bimbingan kelompok antara lain sebagai berikut : (1). Asas Kerahasiaan, semua yang hadir harus menyimpan dan merahasiakan apa saja, data dan informasi yang didengar dan dibicarakan dalam kelompok, terutama hal-hal yang tidak boleh dan tidak layak diketahui oleh orang lain. Para peserta berjanji tidak akan membicarakan hal-hal yang bersifat rahasia di luar kelompok. (2). Asas keterbukaan, yaitu semua peserta

\footnotetext{
${ }^{5}$ Chosiyah, dkk. Layanan Bimbingan Kelompok, Solo: FKIP BK UNS, 2001 Percetakan 35, hlm. 26.

6 Prayitno, Dasar-dasar Bimbingan dan Konseling, Proses Belajar Mengajar, Jakarta: Rineka Cipta, 2000, hlm. 108.
} 
bebas dan terbuka mengelarkan pendapat, ide, saran, dan apa saja yang dirasakannya dan dipikirkannya, tidak merasa takut, malu ataupun ragu-ragu, dan bebas berbicara tentang apa saja, baik tentang dirinya, sekolah, pergaulan, keluarga dan sebagainya. (3). Asas kesukarelaan, yaitu semua peserta dapat menampilkan dirinya secara spontan tanpa disuruh-suruh ataupun maliu-malu atau dipaksa oleh teman yang lain atau oleh pembimbing kelompok. (4). Asas Kenormatifan, yaitu semua yang dibicarakan dan yang dilakukan dalam kelompok tidak boleh bertentangan dengan norma-norma dan peraturan yang berlaku, semua yang dilakukan dan dibicarakan dalam bimbingan kelompok harus sesuai dengan norma adat, norma agama, norma hukum, norma ilmu, dan

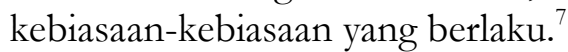

\section{Tahapan Layanan Bimbingan Kelompok}

Bimbingan kelompok pada pelaksanannya memiliki desain/tahapan yang harus diperhatikan, antara lain :

1. Tahap Pembentukan. Tahap ini merupakan tahap pengenalan, tahap pelibatan diri, atau tahap memasukan diri kedalam kehidupan suatu kelompok. Pada tahap ini pada umumnya anggota yang ada saling memperkenalkan diri dan juga saling mengungkapkan tujuan maupun harapan-harapan yang ingin dicapai baik oelh masing-masing, sebagian, maupun seluruh anggota. Memberikan penjelasan tentang bimbingan kelompok sehingga masing-masing anggota akan tahu apa arti dari bimbingan kelompok dan mengapa bimbingan kelompok harus dilakukan serta menjelaskan aturan main yang akan diterapkan dalam bimbingan kelompok.

2. Tahap Peralihan. Tahap ini merupakan tahap jembatan antara tahapan pertama dan tahapan ketiga. Adapun yang dilaksanakan pada tahap ini yaitu : (1) menjelaskan kegiatan yang yang akan ditempuh pada tahap berikutnya, (2) menawarkan atau mengamati apakah para anggota sudah siap \menjalani kegiatan pada tahap selanjutnya, (3) membahas suasana yang terjadi, (4) meningkatkan kemampuan keikutsertaan anggota. Ada beberapa hal juga yang harus diperhatikan oleh seorang pemimpin bimbingan kelompok, yakni menerima suasana yang ada secara sabar dan terbuka, tidak menggunakan cara-cara yang bersifat langsung atau mengambil alih kekuasaannya, mendorong dibahasnya suasana perasaan, dan membuka diri sebagai contoh, dan penuh empati.

3. Tahap Kegiatan. Tahap ini merupakan inti dari kegiatan bimbingan kelompok. Dalam hal ini teknik kegiatan yang dilakukan dildalam bimbingan kelompok adalah teknik permainan simulasi yang dimana dalam prosesnya harus menjadi perhatian yang seksama dari pemimpin kelompok. Ada

7 Prayitno, dkk, Layanan Bimbingan Kelompok dan Konseling Kelompok yang Berhasil, Bogor: Penerbit Ghalia Indonesia, 2017, hlm 238. 
beberapa yang harus dilakukan oleh pemimpin bimbingan kelompok dalam tahap ini, yaitu sebagai pengatur jalannya proses permainan simulasi.

4. Tahap Pengakhiran. Pada tahap pengakhiran bimbingan kelompok, pokok perhatian utama bukanlah pada beberapa kali kelompok harus bertemu, melainkan pada hasil kelompok yang telah dicapai oleh kelompok tersebut. Kegiatan kelompok sebelumnya dan hasil-hasil yang dicapai setidaknya mendorong kelompok tersebut melakukan kegiatan sehingga tujuan kegiatan akan tercapai secara utuh. Adapun beberapa hal yang dilakukan dalam tahap ini adalah pemimpin kelompok mengemukakan bahwa kegiatan akan segera diakhiri, pemimpin dan anggota kelompok mengemukakan kesan dan hasilhasil kegiatan, membahas kegiatan lanjutan, dan mengemukakan kesan dan harapan. ${ }^{8}$

\section{Kegunaan Bimbingan Kelompok}

Kegunaan Bimbingan Kelompok menurut Sitti Hartinah antara lain : (1) tenaga pembimbing masih sangat terbatas dan jumlah individu yang dibimbing begitu banyak sehingga pelayanan bimbingan secara perseorangan tidak akan merata, (2) melalui bimbingan kelompok, individu dilatih menghadapi suatu tugas bersama atau memecahkan suatu masalah bersama. Hal tersebut akan diperlukan/dibutuhkan selama hidupnya, (3) dalam mendiskusikan sesuatu bersama, individu didorong untuk berani mengemukakan pendapatnya dan menghargai pendapat orang lain, selain itu beberapa individu akan lebih berani membicarakan kesukarannya dengan penyuluh setelah mereka mengerti bahwa teman-temannya juga mengalami kesukaran tersebut, (4) banyak informasi yang dibutuhkan oleh individu dapat diberikan secara kelompok dan cara tersebut lebih ekonomis, (5) melalui bimbingan kelompok, beberapa individu menjadi lebih sadar bahwa mereka sebaiknya menghadap penyuluh untuk mendapat bimbingan secara lebih mendalam, (6) melalui bimbingan kelompok seorang ahli bimbingan yang baru saja diangkat dapat memperkenalkan diri dan berusaha mendapat kepercayaan dari peserta bimbingan kelompok.

\section{Sikap Jujur}

Sikap atau dalam bahasa Inggris disebut juga attitude. Attitude merupakan suatu cara seseorang bereaksi terhadap suatu rangsangan atau biasa disebut respon terhadap situasi yang sedang dihadapi. Menurut kamus bahasa Indonesia oleh W.J.S. Poerwodarminto, sikap diartikan sebagai perbuatan yang didasarkan oleh keyakinan atas norma-norma yang ada di suatu masyarakat. Sikap (attitude) dalam buku karya Laura A. King mengartikan sikap adalah berbagai pendapat dan keyakinan kita mengenai orang lain, objek, atau gagasan

${ }^{8}$ Sitti Hartinah, Konsep Dasar Bimbingan Kelompok, Bandung: PT Refika Aditama, 2009, hlm. 132-137.

${ }^{9} \mathrm{Ibid}, \mathrm{hlm} .8$ 
sederhananya, bagaimana kita merasakan berbagai hal ${ }^{10 .}$ Pendapat lain sikap di artikan sebagai bagian dari tingkah laku manusia sebagai gejala atau gambaran kepribadian yang memancar keluar

Jujur, menurut pendapat Naim ${ }^{11}$ merupakan nilai penting yang harus dimiliki oleh seseorang. Menurutnya jujur bukan hanya dari ucapan, tetapi juga harus tercermin melalui kehidupan sehari-hari. Sedangkan menurut Elfindri, $\mathrm{dkk}^{12}$ mengartikan jujur berarti sama dengan lurus hati, tidak berbohong, berkata apa adanya, tidak curang, serta senantiasa mengikuti peraturan yang berlaku. Pendapat lain mengartikan jujur sebagai upaya mengakui, berkata, atau memberikan suatu informasi yang sesuai dengan kebenaran dan kenyataan. Sikap jujur atau kejujuran yang dimiliki individu biasa dihubungkan dengan hati nurani dan pengakuan. Orang yang biasa memiliki sikap jujur, saat berkata ataupun berperilaku tidak sesuai dengan hati nurani, maka akan merasakan kerisauan dan ketidak tenangan. ${ }^{13}$

Dari pendapat para ahli tersebut bahwasanya jujur merupakan suatu nilai yang sangat penting dimiliki seseorang, jujur adalah suatu sikap yang dilakukan individu/seseorang kepada seseorang lainnya tentang apa yang didengar, dilihat serta dilakukannya tanpa adanya pengurangan ataupun penambahan dari apa yang di alaminya serta perlakuannya dadasarkan dengan berpikir positif, berbuat sesuai dengan aturan dan tata nilai, bertanggung jawab atas segala perbuatan yang dilakukan, dan senantiasa berupaya untuk dapat dipercaya oleh lingkungannya.

\section{Tingkatan Jujur}

Jujur mempunyai tingkatan didalamnya, tingkatan tersebut diantaranya terdapat lima bagian, (1). Jujur dalam peerkataan, artinya kejujuran dalam perkataan dapat diketahui ketika seseorang memberikan suatu informasi atau berita. (2). Jujur dalam niat, yaitu yang berkaitan dengan keikhlasan, kejujuran dalam niat dapat diketahui ketika seseorang melakukan sesuatu karena keikhlasan tanpa meminta imbalan. (3). Jujur dalam memenuhi keinginan, bagi seseorang mudah mengungkapkan keinginan, akan tetapi untuk merealisasikannya cukup berat, dalam hal ini diperlukan kejujuran pada diri individu untuk merealisasikannya. (4). Jujur dalam perbuatan, adalah menunjukan kesungguh-sungguhan seseorang dalam mengerjakan sesuatu sesuai

${ }^{10}$ Laura A. King, Psikologi Umum Sebuah Pandangan Apresiatif, Jakarta: Penerbit Salemba Humanika, 2017, hlm. 184

${ }^{11}$ N. Naim, Character Building Optimalisasi Peran Pendidikan dalam Pengembangan Ilmu dan Pembentukan Karakter Bangsa. Jogjakarta: ar-Ruzz Media, 2012, hlm. 132.

${ }^{12}$ Elfindri, dkk., Pendidikan Karakter Kerangkea, Metode, dan Aplikasi Untuk Pendidik dan Profesional. Jakarta: Baduose Media Jakarta. 2012, hlm. 96.

${ }^{13}$ Fitri Nurul, dkk. "Pengarub Sikap Kedisiplinan dan Kejujuran Peserta Didik Terbadap Hasil Belajar Biologi”, Jurnal Biotek, Volume 4 Nomor 1 Juni 2016, hlm. 88. 
dengan apa yang ada di dalamm hatinya. (5). Jujur didalam beragama, yang menjadi kejujuran yang paling tinggi dan mulia. ${ }^{14}$

Penjabaran tersebut diatas, senada dengan pendapat dari Irwan (2014) yang mengatakan bahwa tingkatan kejujuran terdiri dari jujur dalam berbicara, jujur dalam niat, jujur dalam merealisasikan, jujur dalam bertindak, dan jujur dalam beragama. Sikap jujur harus di punyai seseorang dari sejak dini, kejujuran dapat dibentuk, menurut Prayitno dan Afriva Khaidir (2011), dan Tim Penyusun P3N-KC (2011) menyatakan nilai karakter cerdas jujur adalah bahwa individu mampu berkata apa adanya, berbuat atas dasar kebenaran, membela kebenaran, bertanggung jawab, memenuhi kewajiban dan menerima hak, lapang dada, serta menegang suatu janji. ${ }^{15}$

\section{Bimbingan Kelompok Membentuk Sikap Jujur Melalui Pembiasaan}

Sebagaimana mengembangkan karakter jujur diperoleh melalui pembiasaan, maka berbohong/berdusta pun yang merupakan perilaku menyimpang tentunya diperoleh dari pembiasaan. Pembiasaan merupakan sesuatu yang sering dilakukan dalam kehidupan sehari-hari. Hal ini tercermin dalam tingkah laku seseorang untuk melakukan sesuatu. pembelajaran manusia yang lebih kompleks membutuhkan penggabungan dari prinsip-prinsip pada kajian tentang pembiasaan, Layanan bimbingan kelompok yang fungsinya sebagai proses pemberian informasi dan bantuan pada sekelompok orang dengan memanfaatkan dinamika kelompok guna mencapai suatu tujuan tertentu. Dalam layanan bimbingan kelompok interaksi antar individu antar anggota kelompok merupakan suatu yang khas yang tidak mungkin terjadi pada konseling perorangan. Bimbingan kelompok dalam upayanya membentuk sikap jujur harus menggunakan pembiasaan yang ada keterkaitannya dengan membentuk tingkah laku.

Sikap jujur dimaksudkan dalam proses layanan bimbingan konseling yaitu suatu sikap klien yang terbuka, autentik, dan asli (genuine). Sikap jujur sangat penting dalam konseling, karena sikap keterbukaan memungkinkan konselor dan klien menjalin hubungan psikologis yang lebih dekat dalam proses konseling. Selain itu, kejujuran memungkinkan konselor memberi umpan balik secara obyektif kepada klien, terkhusus didalam lingkup proses layanan bimbingan kelompok. Hal ini berkaitan dengan pendekatan tingkah laku atau behavioral yang menekankan pada dimensi kognitif individu dan menawarkan berbagai metode yang berorientasi pada tindakan (action-oriented) untuk membantu mengambil langkah yang jelas dalam mengubah tingkah laku.

\footnotetext{
${ }^{14}$ Juliana Batubara, "Pengembangan Karakter Jujur Melalui Pembiasaan", Jurnal Konseling dan Pendidikan, Volume.3 No. 1, Februari, hlm. 1-6, hlm. 3.

${ }^{15} \mathrm{Ibid}$, hlm. 3.
} 
Dalam penyelenggaraan pembiasaan seorang pembimbing perlu memperhatikan beberapa prinsip. Menurut Henry C. Ellis prinsip pembiasaan adalah sebagai berikut ${ }^{16}:$ (1). Acquisition (Perolehan). Respon yang memperoleh penguatan akan menguat secara berangsur-angsur dan sebaliknya. (2). Extinction (Pemadaman). Pemadaman merupakan penurunan intensitas kekuatan respon yang semakin sering tidak terlihat sampai menghilang. (3). Spontaneous Recovery (Pengembalian Spontan). Pengembalian spontan menunjukkan munculnya kembali respon yang telah mengalami pemadaman. Ini menunjukkan bahwa kecenderungan perilaku masih ada walaupun respon telah dihilangkan sebelumnya. (4). Generalization (Generalisasi). Belajar pada satu situasi atau konteks bisa digeneralisasikan pada konteks atau situasi yang lain, namun yang situasinya mirip. Dengan demikian prinsip dasarnya adalah bahwa suatu respon yang dipelajari pada sutua stimulus dan ada stimulus lain yang mirip dengan itu, maka akan menghasilkan respon yang sama. (5). Discrimination (Pembedaan). Proses pembelajaran untuk memberikan respon secara berbeda-beda terhadap stimulus yang mirip dinamakan dengan pembedaan stimulus. Proses ini merupakan bentuk dasar dari semua pembelajaran. Faktor-faktor yang mempengaruhi pembedaan stimulus antara lain, kemiripan, kekonsistenan dan dimensi kerelavansian. Semakin besar tingkat kemiripan semakin sulit orang membedakannya. (6). Differentiation (Perbedaan). Perbedaan adalah proses yang mirip dikuatkan secara berbeda. Dalam hal ini satu respon dikuatkan sementara respon yang lain dilemahkan.

Berdasarkan uraian di atas prinsip pembiasaan sangat diperlukan dalam proses pemberian bantuan khususnya dalam pembentukan sikap jujur. Indivdu akan tetap melakukan suatu kebaikan jika mendapatkan respon yang positif dari lingkungan, maka peran konselor harus mampu memposisikan dirinya dalam keadaan bimbingan berkelanjutan dengan pengontrolan pemberian layanan bimbingan kelompok dengan pembentukan sikap jujur.

\section{Penutup}

Dari pembahasan yang sudah dipaparkan diatas, dapat disumpulkan bahwa layanan bimbingan kelompok merupakan upaya bantuan bimbingan konseling untuk melakukan bimbingan yang dalam prosesnya memanfaatkan situasi kelompok atau gabungan dari beberapa individu yang menjadi satu kesatuan lingkup kelompok.

Upaya dari adanya layanan bimbingan konseling khususnya layanan bimbingan kelompok mempunyai keterkaitan dengan pembiasaan yang dilakukan konselor berupa informasi-informasi kejujuran, dengan harapan menjadikan peserta bimbingan kelompok memiliki kebiasaan untuk selalu

\footnotetext{
${ }^{16} J u l i a n a$ Batubara, "Pengembangan Karakter Jujur Melalui Pembiasaan", Jurnal Konseling dan Pendidikan, Volume. 3 No. 1, Februari, hlm. 1-6, hlm. 5.
} 
bersikap jujur,dalam prosesnya bimbingan kelompok menganjurkan setiap anggotanya untuk mengungkapkan berbagai hal baik itu tanggapan sebagai pengalaman yang bisa di berikan kepada anggota kelompok bimbingan lainnya, maupun pengalaman pribadi dirinya secara terbuka, tujuan layanan bimbingan kelompok tersebut memberikan kontribusi kepada setiap anggota yang ada didalam proses bimbingan kelompok untuk bersikap jujur dalam berbagi pengalamannya tersebut. 


\section{Bibliografi}

Arifin, Syamsul, Bangbang. Dinamika Kelompok. Bandung : CV Pustaka Setia, 2015.

Elfindri, dkk.Pendidikan Karakter Kerangka, Metode, dan Aplikasi Untuk Pendidik dan Profesional. Jakarta : Baduose Media, 2012.

Hartinah, Sitti. Konsep Dasar Bimbingan Kelompok. Bandung : PT Refika Aditama, 2009.

King A. Laura.Psikologi Umum Sebuah Pandangan Apresiatif, Jakarta :Penerbit Salemba Humanika, 2017.

Naim, N. Character Building Optimalisasi Peran Pendidikan dalam Pengembangan Ilmu \& Pembentukan Karakter Bangsa. Jogjakarta: ArRuzz Media 2012.

Prayitno.Dasar-dasar Bimbingan Konseling, Proses Belajar Mengajar. Jakarta : Rineka Cipta, 2000.

Prayitno, Afdal, dkk. Layanan Bimbingan Kelompok dan Konseling Kelompok . Bogor: Ghalia Indonesia, 2017

Romlah, Titiek. Teori dan Praktek Bimbingan Kelompok. Malang : Penerbit Universitas Negeri Malang, 2001.

Samani, M. Dan Hariyanto. Konsep dan Model Pendidikan Karakter. Bandung : PT Remaja Rosdakarya, 2012.

Juliana Batubara, "Pengembangan Karakter Jujur Melalui Pembiasaan", Jurnal Konseling dan Pendidikan, Volume.3 No. 1, Februari, hlm. 1-6, hlm. 3.

Nurul Fitri, dkk. "Pengaruh Sikap Kedisiplinan Dan Kejujuran Peserta Didik Terhadap Hasil Belajar Biologi", Jurnal Biotek, Volume 4 Nomor 1 Juni 2016. 
178 | Islamic Counseling: Jurnal Bimbingan dan Konseling Islam, Vol. 3, No. 2, 2019 